\title{
ZAKAT AND WAKAF (ENDOWMENTS) ROLE IN MUSLIMS ECONOMIC DEVELOPMENT OF ISLAMIC ECONOMIC PERSPECTIVE
}

\author{
Usman Zainuddin Urif*, Mahillatul Iffa Nuril Fajria**, Ulfatu Rahmi*** \\ Hamzanwadi Islamic Institute \\ *usmanzainuddimurif@gmail.com
}

\begin{abstract}
This research aims to determine and comprehen about zakat and waqf role in the economic development of the Muslims (Ummah) in Islamic economic perspective. Research types is library research. Research approach using combination of a philosophical and phenomenological approach. A philosophical approach is used to look deeply at philosophical material objects such as values, principles, Islamic economic goals and rakat and wakaf role in Muslims (ummab) economic development. While the phenomenological approach is used to look at the economic development that is reflected in society through statistical data about poverty, as well as those contained in a literature work such as books, documents, scientific works and research. Study result: Islamic economic system aims is to improve society welfare and to realize maqasid as sharia, and uphold justice value, therefore the important base of zakat and waqf distribution is Allah guidance in Qur'an Surah (chapter) [59]: 7 .... " so that the wealth should not circulate among the rich people among you... "from these foundation spawned a great concept of zakat and waqf role in economic development. Zakat and waqf are economic development instruments. Empowerment and management of coordinatively between government and society make a positive contribution in Muslims economic development.
\end{abstract}

Keywords. Muslims Economic, Zakat, Wakaf (endowment), Developement

\section{PREFACE}

One of the problem that humans faced in their daily lives is an economic problem. Economic problems often having a negative impact on people's social life such as; poverty, social status gap, inequality income and so on. Social gap is one of economic development problems. Economic gap appearance raises a lot of problem, such as increasing the number of poor families, rising unemployment, crime rates increase, decreased education quality, health quality decreases and purchasing power decreases. all people crave a life of well-being; such as clothing, food, shelter, education and health costs, but some people have not reached it with diverse causes, unemployment, less even there is no land for farming, lack of employment or limited

Islamika : Jurnal Keislaman dan Ilmu Pendidikan

Volume 1, Nomor 2, Juli 2019; 133-153

https:// ejournal.stitpn.ac.id/index.php/islamika 
employees or workers who are accepted. more labor force than employment. Another reason is inadequate knowledge and skills. This is an obstacle and a problem to get a job. The biggest cause of deprivation of people's rights committed by some people who are greedy and immoral, even though the earth with all its contents was created by God to be maintained and managed properly, for human prosperity in the world and hereafter. He created this nature in pairs such as changing day and night, heat and cold, rain, wind, air and others for human life benefit (maslahah). Life suffering such as poverty, ignorance, and backwardness, bring up various problems, like children split up from their parents, divorce, even leave for years to earn a living to fulfill their daily needs. This farewell to many years can be caused by each family member who has a problem because of a parent, child, husband or wife.

Economic development is an economic prosperity developement effort of a country or region for its population welfare. Economic development is defined as a process to increase per capita income. Economic development is closely related to poverty, because poverty is one of the causes of economic development efforts. Underdeveloped countries and developing countries are generally entangled in what is called the vicious cycle of poverty. The vicious circle means a circular forces sequence from each other in action and reacts in such a way as to place a fixed area in a time of destitute. The poor, for example, are always at risk of eating, lack of food makes health worse and physically weaker so ability to work is also reduced and make low income. poor conditions if associated with a country it can be packaged into an ancient proposition "a poor country because he is poor" ${ }^{1}$

The vicious circle basically derives from the fact that total productivity is very low as a result of capital lack, economic backwardness and imperfect markets. vicious circle viewed from demand angle show that low income levels followed by low demand, as well as investment at low levels. The low investment level causes lack of capital and low productivity. Low productivity is reflected in low real income, etc.

In the economic system, Islam adheres to justice and honesty principle. In Islam, humans are God's caliphs or representatives in all of God's plans, and have been given limited ownership rights to the means of production. Islam recognizes

${ }^{1}$ Nurkse, Problem of Capital Formation in Underdeveloped Countries, hlm.4 
the existence of state interference in economic activities to ensure the welfare of its citizens. Elimination of interest/ usury (riba), zakat institutionalization, infaq and shadaqah, waqf institutionalization, halal and haram tconcept, fair and equitable wealth distribution, hoarding prohibition and emphasizing the importance of wealth circulation, concentrate on poor welfare are characteristic of Islamic economic systems. The basic goals of Islamic economics is to realize the happiness (falah) of Muslims in the world and in the hereafter, and to realize brotherhood among society members. This goals cant be achieved if wealth distribution among community members is unfair and evenly distributed, there is a wide gap between the rich and the poor and inter-class conflicts occur in the community.

Islam has provided guidance in eradicating poverty and socio-economic disparity in society through commands to try and work hard, commands to pay zakat, infaq, shadaqah and waqf (endowments). Expenditures of zakat, infaq, shadaqah and waqf as a means to narrow the gaps and differences in society income which can prevent social disparity conflict, security and harmony disruption in society. With the payment of zakat, infaq, shadaqah and waqf, it is hoped that it can improve people welfare, especially those who are entitled to receive so can live properly and independently without relying on others ${ }^{2}$.

The Islamic economic system tries to enforce wealth distribution rules evenly among members of the Muslim community by taking very effective actions. Allah (God) gives instructions with His word; "... so that the wealth should not circulate among the rich people among you ......" (QS. [59]: 7. it shows that wealth should not form a circle among the rich only, but must remain in circulation among all members of the community and fulfill all people need. Allah cursed and threateneds people who hoarded their treasure ... And those who keep gold and silver and do not spend them on the path of Allah, tell them (that they will get) a painful punishment "(Qs. [9]: 34

Wealth means "having lots of assets (money etc.), wealth means" property (objects) that belong to people "3. plural word of Asset or maal is amwal,

\footnotetext{
2 Nasruddin Rozak, Dienul Islam, Al Ma’arif, Bandung, 1985, hlm .19

${ }^{3}$ Pusat Bahasa Departemen Pendidikan Nasional, Kamus Besar Bahasa Indonesia, Balai Pustaka, Jakarta, 2005 hlm 519
} 
etymologically has several meanings, namely leaning, tending and tilting. Accordance with the human nature tendency to own property. There are also those who interpret al -mal with something that pleases humans and they guard it, both in material and utility. There are also those interpret something that is needed and obtained by humans in the form of objects look like gold, silver, animals, plants and others, as well as those that are not visible, namely benefits such as vehicles, clothing, shelter etc.

In terms of terminology, assets or maal is something that humans want based on their character, whether they will give it or save it. Something that cannot be saved cannot be called a treasure. Therefore, according to Hanafiyah the utilty and property (own) are not called treasure. it distinguishes between assets and property (own). A treasure is a valuable material substance ('ain) that rotates between humans ${ }^{4}$. Property is what can be owned, controlled, cultivated, transferred, both tangible and intangible objects, both fixed and undetected objects, both movable and immovable objects and rights which have economic value. ${ }^{5}$

Assets or property in Islam view occupies a very important position. Islam places wealth as one of the five basic needs in human life that must be fulfilled (ad dharuriyah al khamsah). Ad dharuriyah al khamsah sequentially includes maintaining religion, soul, mind, lineage and wealth (al din, al nafs, al aql, al nasl, al mal) ${ }^{6}$. Although assets occupy the fifth rank of all aspects of ad dharuriyah al khamsah, assets are something is very urgent in the maintenance of forth others aspects. For example, performing prayer as a manifestation of the religion maintenance, humans need clothes to cover genitals. Fulfill soul needs with food and drink. Fullfill sense needs with knowledge and assets. fulfill the continuation of descent needs with a legal marriage also achieved with assets. So assets or property is something vital in human life.

In order to fulfill basic needs (dharuri), humans are told to work for sustenance. God's (Allah) command is contained in QS. [62]: 10, "When praying is

\footnotetext{
${ }^{4}$ Rahmat Syafei, Fiqh Muamalah, Pustaka Setia, Bandung, 2000 hlm 21

${ }^{5}$ Mardani, Kompilasi Hukum Ekonomi Syariah dalam Fiqh Ekonomi Syariah, Prenadamedia Group, Jakarta, 2013, hlm 60

${ }^{6}$ Abu Ishak as Syathibi, al Muwafaqat fi ushul al Syariah, Dar al Ma'rifah, t.t. hlm.8
} 
done, you will scatter on the face of the earth, seek Allah grace and remember Allah as much as possible so that you are lucky." Treasure serves as a support for human life, wealth is not an essential purpose, but only as a mean to achieve purpose life and the God pleasure (Allah's ridha) or for a personal and community goodness. Property as a means to achieve goodness and life jewelry and joint welfare benefit human life. " Assets and children are jewelry of world life, but only deeds that are eternal, piety is better reward on the side of your Lord and better to be hope " (Qs. [18]: 46. Assets are blessings from Allah with them Allah tests the owner, whether grateful or kufr, and know that your wealth and children are only a trial and in fact with Allah's great reward (Qs. [8]: 28.

Treasure or property in Islamic view in its essence belongs to Allah, humans duty is maintaining and managing it. Humans only manage, utilize and distribute it for the benefit and survival life on earth. Human rights to treasure or wealth are limited to utilization rights and management accordance with Allah's outlined as the universe absolute owner. Allah (God) as absolute owner and producer of property, so the part of Allah in property is dominant. But Allah does not need anything. Therefore, the large and dominant part of God, as a logical consequence, must flow to poor, needy, poor and disadvantaged society members. God's part in wealth distribution sometimes collected in the form of compulsory levies such as zakat, zakat fitrah (holy), ransom etc. Sometimes in voluntary charity form such as infaq, and sadaqah.

\section{RESEARC METHOD}

Research type. Research uses a qualitative approach with the type of library research. Research is Zakat And Waqf (Endowments) Role In Muslims Economic Development Of Islamic Economic Perspective. Study approach is a combination of a philosophical and phenomenological approach. A philosophical approach is used to look deeply at philosophical material objects such as values, principles, Islamic economic goals, zakat and waqf role in the economic development. While the phenomenological approach is used to look at economic development both illustrated in society via statistical data on poverty, as well as those contained in a literature work such as books, documents, scientific works and research. 
Data collection technique. The techniques used in collecting data are observation, interviews and documentation using a qualitative analysis with inductive mindset, used an interactive method as stated by B. Milles and A. Machael Hubermen, which consists of three types of activities: data reduction, data presentation and conclusion before, while and after data collection.

\section{RESULT AND DISCUSSION}

\section{Islamic Economic System}

a. Value, Principle and Goal

Disagreements appear about an economic concept, based on the different values enterance both in theory and economic policy, including the Islamic economic system (SEI). In particular, the values in the Islamic economic system (SEI) sourced from the Qur'an and the Sunnah which are the basic of the view islamic life. In facing the new era and transformation in society, the Islamic economic system (SEI) always referring to the Qur'an and Sunnah. All growing problems, including economic problems must remain subject to sharia principles ${ }^{7}$. The existence of values on economic behavior can produce a normative economy unable flows dynamically.Therefore, the implementation must be jointly based on economic principles. These principles will make Islamic economic buildings sturdy and dynamic, and this is what functions to color the quality of the building $^{8}$

Economic values in Islamic view, among others: first, Justice, by upholding the values of truth, honesty, courage and consistency in the truth, second, Accountability, to prosper the earth and the universe as the duty of a caliph. Every economic actor has the responsibility for correct economic behavior, a mandate in realizing benefit (maslahah). Also has the responsibility to improve community welfare than personal or specific

\footnotetext{
${ }^{7}$ M.A.Mannan, Teori dan Praktik Ekonomi Islam, terj.M. Nastagin, Dana Bhakti Wakaf, yogyakarta, 1997. Hlm 10-11.

8 P3EI Univ.Islam Indonesia, Ekonomi Islam, Rajawali Pres ( Rajagrafindo Persada, Depok, 2013, hlm.58
} 
group, third, Takaful (Social Security), the existence of social security in the community will encourage the creation of good relations between individuals and society, because Islam put vertical and horizontal relations in a balanced way $^{9}$

Basic Islamic economics value inspire Muslim communities in carrying out their socio-economic activities. In line with Islamic teachings about human relations with himself and social environment, which according to Naqvi is represented by four ethical axioms namely; Tawhid, Balance (equilibrium), Free will, and responsibility (responsibility) ${ }^{10}$. Tawheed, Islam main source teachings that fully believe in God and vertical dimension of Islam. Creating human relations with God and unconditional surrender of human beings to all actions to obey His (Allah) commandments, so that everything done must be in accordance with outlined. Balance (equilibrium/ al adl), Principle that refers to social ideals. balance principle and alignment applies to all basic policies for all social institutions, both legal and political. Especially in the economy the balance principle becomes the basic for the production, consumption and distribution. Free will, ability to make choices to make humans as caliphs on earth. Freedom in making choices has accountability consequences for what has been chosen so that humans are required to be in the right choice. Man is given to choose two choices, namely, whether he makes the right choice guided by the truth or vice versa. Responsibility, this axiom is close to free will, but it does not mean the same as free will. Islam gives great attention to the concept of responsibility, by establishing a balance between free will and responsibility. The concept of responsibility take to the actions carried out must give as much as possible (maslahah) to the public, and the concept of voluntary responsibility in born from itself with no forced and awareness to be a better person ${ }^{11}$

\footnotetext{
${ }_{9}^{9}$ Ruslan Abdul Ghafur Noor, Konsep Disteribusi Dalam Ekonomi Islam, Pustaka Pelajar, Yogyakarta, 2013, hlm.63

10 Syed Nawab Hedar Naqvi, Islam Ekonomics and Society, Kegan Paul International, UK, 1994. Hlm 26

11 Ruslan Abdul Ghafur Noor, op.cit, hlm 63-65.
} 
Islamic economic system principle and goals sourced from the Qur'an and the Sunnah which are developed and elaborated by ulama (Muslim Dominie) and scholars. Principle of Islamic economic systems include; first, tawheed (monotheism), take an awareness of full responsibility to Allah, and comprehen economics as a command of Allah. Economic activities not only prioritize economic value, but also recognition that Allah is one God so that what is done must be with full responsibility, secondly, the caliph, awareness as the representative of Allah on earth take to the right economic attitude according to syar'i guidance, having an economy for the benefit of mankind, realize justice and prosperity for all humans. ${ }^{12}$.

The foundation of Islamic economic system includes; aqeedah, sharia and akhlaq (morality). Aqidah views economic activities as divine and rabbaniyah activities, sharia considers that legal economic activities may be in accordance with the principles of ushulfiqh, and all rules in Islamic economics are enforced to realize benefit and eliminate damage (mafsadat), morality, enforce norms and ethics which are the spirit of the Islamic economy by transforming transcendental ethics (ethics originating from the Qur'an and the Sunnah) in all economic activities ${ }^{13}$

In addition, Islamic economic systems also have goals to be achieved. The aim of the Islamic is to improve all human beings welfare, locate in protecting the five basic needs (ad dharuriyah al khamsah), faith protecting (ad-din), soul protecting (an-nafs), mind protecting (al-aql), descent protected (an-nasl), property protected (al-mal). ${ }^{14}$ Sistem ekonomi Islam bukan hanya bertujuan untuk menciptakan kesejahteraan semata, namun juga menjamin terwujudnya tujuan syar'i. Hal inilah yang membedaakan secara jelas tujuan sistem ekonomi Islam dengan sistem ekonomi konvensional yang tidak memberi tempat pada unsur keimanan ${ }^{15}$. Islamic economic goals is mashlahah (benefit) for mankind by seeking

\footnotetext{
12 Ibid, hlm 65-66

${ }^{13}$ Ika Yunia Faauzia, dkk, Prinsip Dasar Ekonomi Islam, Prenadamedia Group, Jakarta, 2015, hlm12

14 M.Umar Chapra, Islam and Economic Development, Islamabad, IIIT, 1993, hlm 5.

15 Ruslan Abdul Ghafur Noor, op.cit, hlm.67
} 
activities that can directly realize the benefit itself. Another activity to achieve benefit is to avoid all things that bring mafsadah (damage) to humans $^{16}$

\section{b. Islamic Economic System, Capitalist \& Socialist Economic System}

Islamic economic system (SEI) outlines the values, principles and goals sourced from the Qur'an and the Sunnah in economic behavior. This three outline element become the foundation in all economic processes, both in production, consumption and distribution activities, so that they distinguish them from other economic systems. The three basic elements that distinguish Islamic economic systems from the capitalist economic doctrine, socialist place at principles in ownership, economic freedom with clear boundaries, and justice principle ${ }^{17}$. These three things is a basic form of an important element in distinguishing Islamic economic systems with others systems, especially when knowledge of economic system is co-opted by two main economic system, capitalist and socialist. These two systems dominate economic system in the world. ${ }^{18}$

These two mainstream world economic systems, first born of continuous intraction between the two system, which are contradictory in offering economic theory. Adam Smith thought (1723-1790) who first comprehensively compiled and affirmed the ideas of capitalism so that it would later be known as pure capitalism. As well as Karl Marx offer (18181883) to the answer of welfare gap classess, which later became the pioneer of the socialist system, it showed intense intraction of two systems to produce internal evaluations of the original system, and systems developement. In the capitalist system the awareness of the failure of the pure capitalist system in realizing prosperity, bring up to a capitalist system governed by state capitalism who carried by Friedrich List (1789-1846). The system of state capitalism was also completed by Adolf Wagner by offering

\footnotetext{
${ }^{16}$ Ika Yunia Fauzia, dkk, lok, cit

${ }^{17}$ Muhammad Baqir Sadr, Iqtisaduna (Our economic), Wofis, Teheran, 1994, hlm.51

18 Syarfuddin Prawiranegara, Peranan Agama dan Moral dalam Pembangunan Masyarakat dan Ekonomi

Indonesia, Bulan Bintang, Jakarta, 1966, hlm.30
} 
the concept of walfare state. Furthermore, this capitalism system was corrected by J.M. Keynes (1936) which offered a mixed economy system ${ }^{19}$

So about socialist system, the ability to evaluate weaknesses internally, bring up to many figures and thoughts in this system. Started by Karl Heindrich Marx views (1818-1883) who were balked capitalist thought by Adam Smith, he considered capitalist have brought injustice and make social problems sourced from capitalist motive to find an endless means of selfsatisfaction. Marx's view is expressed in real terms in dialectical materialism theory, historical materialism and das capitalist. Marx's thinking was developed by Althusser with structuralism theory, Antonio Gramsci with his hegemony theory, Samir Amin and Andre Grunder Frank with dependency theory. ${ }^{20}$

Economic system have the same problems but are different in solving and last system is the system that most able to realize community goals according to existing social system.

From the development of economic system thinking, it can be seen the prominent differences in applied economic policies. Differences in policy are taken to answer the three basic questions of each economic system that can be distinguished as follows; Capitalist,1.Ownership, private ownership of the means of production, 2. Utilization, humans are free to use based on the motive of seeking maximum profit (profit motive), 3. individuals and countries role in utilizing resources, absolute role private (decision are taken in the market place), 4. Income Distribution, small government interference, based on market mechanisms (a minimum role for the government). Socialist, 1. Ownership, public ownership, removes individual ownership (public ownership of mean of production), 2. Utilization, based on motives public needs, humans are free to use it for the public interest (public good is the motive), 3. Absoluts State role, (decisions are based on planned are taken), 4. Distribution of income, government dominant role, the government as the center of all economic activities. Islamic economics, 1.

${ }^{19}$ Ruslan Abdul Ghafur Noor, op.cit. hlm.72

${ }^{20}$ Ibid, hlm 72-73 
Ownership, God is the absolute owner, humans have limited rights, 2. Utilization, following the instructions and God provisions, 3. Individuals and state role is to realized for people benefit (maslahah), 4. Distribution of income, based on the community, government and market.. ${ }^{21}$

\section{Economic Developement in Islamic Perspective}

\section{a. Definition and Economic Developement Aspect}

Economic development and developing economics alternately used with the same definition, although different in orientation. Economic development Is prosperity developement of economic state or region for society welfare. Economic Developement study as known as development economics). ${ }^{22}$ Economic Developement used alternately with Economic growing, Economic prosperity dan Economic progressing. Economic developement refers to developed countries, while Economic develoving refers to developing countries.

Economic developement has the same meaning and purpose as economic growth, economic welfare, and economic progress. when it manifest and continously economic developement can interpreted as a process which can incerased population income. There are 3 (three) important element related with economic developement ${ }^{23}$ i.e. ; first, Economic developement measured by increase in real national income in long time. Real national income is an output of finished good and services in these country on the real form or non fictive, second, economic developement will get increase when real output per capita get increase. Its possible for economic development, increased real income rate should be higher than population growth rate, third, economic development of economic welfare point is a process where Income per capita increases coincided with community gaps reduced and fulfilment community wishes, but what happen is contrary, it means there are inequality in goods and

${ }^{21}$ Ibid, hlm. 73- 75

22 Mit.Wijaksono, Pembangunan Ekonomi dan Ekonomi Pembangunan, Telaab istilah dan Orientasi dalam Konteks Studi Pembangunan,JESP Vol.1 No.1 2009, di kutif dari Yahoo.com.

23 Okun dan Richadson, Ekonomic Development Concepts and Meaning. In Studies in Economic Development, New York, 1961, hlm 52- 55 
services distribution. Economic development must be manifest of improvement on materials welfare continuously, for long time and smoothly to reduced gap significantly. ${ }^{24}$

\section{b. Economic Development paradigm}

Development paradigm dependent on economic growth. Economic growth is the process of increasing the production of an economy realized in national income increase. economic growth a country termed good when the country's real Gross Domestic Product increases, and one of indicator for measuring economic development. ${ }^{25}$ But it hasn't been said either if economic growth is not coupled with a significant poverty reduced, uneven distribution created high gaps between poor and rich people. Gap is one of the problems in economic development and bring up such problems like; Increasing poverty, unemployment increases, crime rates increase, education quality decreases and the purchasing power of the public decreases. Therefore, in the framework of economic development should be considered in addition to the pursuit of economic growth, also view distribution equalization measure.

\section{c. Economic Development paradigm Islamic Perspective}

Islamic concept about economic development is more spacious than conventional concepts which has measuring by economic growth rate. Base of Islamic economic development is multidimension: moral dimension, social dimension, politic and economic dimension. Islamic Economic development not only material, but moral and spiritual more instrumental and integrated. Allah said which means "For the sake of his soul and refinement (bis creation), Allah inspired the soul (the way) of his ungodliness and steadliness, in fact Fortunate person who purified his soul, and actually loss of the person who authorized him "Qs, asy Syams [91]: 7-10,

In Islamic view poverty is something which can endanger behaviour (akhlaq), logical think, family and society. Islam considers poverty as disasters. Rampant poverty will make people forget God and loss of social taste to others. Person who too wealthy, his wealth can make him a wronged, both wrongly to

${ }^{24}$ Nurul Huda dkk, Ekonomi Pembangunan Islam, Prenadamedia Group, Jakarta, 2015, hlm 4-5

${ }^{25}$ Ibid, hlm 8 
God, wronged to his fellow man and wronged himself. ${ }^{26}$ To overcome poverty is by Islamic economic system applied with charactristic, as effort and work, accumulating property prohibition, Zakat, heir, Waqf, Ghanimah and save. ${ }^{27}$

\section{Islamic Economic Development Instrument}

\section{a. Zakat and zakat role}

Etymologically zakat is developing, increase. Arabian said zakaa az zar'u when az zar'u (plant) these developing and increased. Zakat an nafaqatu when nafaqab (living cost) it blessed. ${ }^{28}$ Sometimes zakat means "holly", (Qs. asy Syams [91]:9), Zakat in Hadits Rasulullah PBUH (Peace Be Upon Him), include History Hadits of Imam Bukhari and Muslim, formulate definition of zakat unclearly. From 72 (seventy two) nash hadits zakat books apparently dominated by shadaqah (voluntary donation), infaq (include self spending and relatives), read al Qur'an (seek for science), Promptly pay the debt (Prioritize the obligation of pleasure). Only 6 (six) pieces zakat words found in nash of hadist shaheeh Bukhari and Muslim. ${ }^{29}$

In Terminology or in fiqh term, Islamic jurist (fuqaha') zakat is a number of treasures that Allah require to be summited to the right/specific person. ${ }^{30}$ Malikiyah: zakat is issued a certain portion of a certain property that has been until it get nishab to the person who is entitled to receive, if the ownership, haul (even one year) has been perfect in addition to the mining goods, safety and findings. Hanafiyah: granting ownership rights to a certain property of a certain property to a particular person who has been determined by the sharia, only for Allah. The word granting of proprietary rights does not enter into it something that the law can. The word part of the treasure issued (does not include) the benefit of goods (property). Certain treasures are it that have been determined according to the Syara'. Certain people are those who are entitled to receive zakat. Syafiiyah: zakat is ame for goods issued for

${ }^{26}$ Ibid, hlm, 23-24

${ }^{27} \mathrm{Ibid}, \mathrm{hlm} 25$

${ }^{28}$ Zuhaili, Al Figh Al Islam Wa adillatubu, jld 2, Dar al Fikr, Damaskus 1989, hlm. 164

${ }^{29}$ Rusli, 2005, hlm.42

${ }^{30}$ Qardhawi, Kiat Islam dalam mengentaskan kemiskinan, Gema Insani Press, 1995, hlm 86 
property or body (human beings for zakat Fitrah) to certain parties, while Hanabilah: zakat is Certain rights to a particular asset to a particular group at a certain time. ${ }^{31}$. Zakat is One of the pillars of Islam which is the obligation of religion that is charged for one's property according to certain rules ${ }^{32}$. According to Imam Nawawi: the amount issued from wealth is called Zakat because the issued number is a lot, making more meaningful and protecting destruction wealth, while according to Ibn Taymiyah, the soul of the people who make zakat become clean and meaning his wealth will be Increases. Increase and growing meaning is not only for the intended property but farther than that ${ }^{33}$ Zakat is a certain right that God (Allah) is obliged to Muslims treasures that are destined for the poor and the other mustahics as a token of gratitude for God's (Allah) favor and to draw closer to him and cleanse himself and his property ${ }^{34}$ Zakat has the meaning of removing part of the property with certain requirements to be given to certain groups (Mustahik) with certain requirements anyway. According to the law of RI No. 38 year 1999, the intent with Zakaah is a property that must be set aside by a Muslim or a Muslim-owned body in accordance with the provisions of the religion to be given to the right to receive $\mathrm{it}^{35}$ Contemporary Islamic economist defines Zakat as a property set by the government or authorities to the general public or the individual who is binding and final without earning certain government-imposed rewards According to the ability of the property owner allocated to fulfill the needs of eight groups that have been determined by the Qur'an and to fulfill the political demands for Islamic finance ${ }^{36}$

As a social economic institution that was born in the 7th century, Zakat is the first fiscal system in the world that has the completeness of

\footnotetext{
${ }^{31}$ Zuhaili, ibid, hlm 165

32 Ali, Sistem ekonomi Islam, Zakat dan wakaf, UI Press, Jakarta 1988, hlm 8

33 Qardawi, ibid,

${ }^{34}$ Hasan, Zakat dan Infak salah satu Solusi Mengatasai Problema Sosial di Indonesia, Prenada Media Group, Jakarta 2015 hlm, 12

${ }^{35}$ Ali, Zakat sebagai Instrumen Dalam Kebijakan Fiskal, RajaGrafindo Persada, Jakarta, 2006, hlm 56.

${ }^{36}$ Inayah, Teori Komprehensip tentang Zakat dan Pajak, TiaraWacana, Yogyakarta, 2007
} 
extraordinary rules, ranging from the subject of the zakat payer, the object of Zakat property (Mal al Zakah), the magnitude of its tariff Each (Miqdar al Zakah), limit of property ownership (the haul), to the allocation of distribution of the Zakat recipient (MUSTAHIQ). Zakat obligation in Islam has a very fundamental meaning, in addition to dealing closely with aspects of the Godhead, also closely related to the social and economic aspects.

The word zakat and prayer is held in the Qur'an by Allah SWT because the position of zakat and prayer is the same as a principle of worship and is a pillar of Islam, so to implement and to present it is an obligation for every Muslims Individual. Even Rasulullah Muhammad SAW placing zakat as one of the main pillars in establishing Islamic religion, his hadith narrated by Imam Bukhari and Muslim meaning "Islam is you worshiping God and do not realize it, you Pray, pay obligatory zakat, fasting Ramadan month and perform Hajj to Baitullah if you can do it ". While the aspect of social justice (Al Protoplast al Ijtimaiyah), the order of Zakat can be understood as a unity of the system inseparably in the achievement of socio-economic and societal welfare.

Attributed to two kinds of relationships as mentioned above, then devotion to God can be understood in two forms; First, devoted to Allah directly or so-called worship in a special sense (Mahdlah) and secondly, devoted to God by doing good to fellow man or called Indirect worship (Ghairu Mahdlah/Muamalah). The manifestation of devoted to Allah by doing good to our fellowmen essentially appears in the form of mutual help (Qs al Maidah [5]: 2). The necessity of each other help is based on the fact that man can not live alone, man needs one another because the natural man is not perfect and weak and in himself there are shortcomings that Can only be fulfilled by others. The disadvantages of one person are not the same as the shortcomings of others. This distinction leads to differences in the possibility of trying to get his life in excess and some others have it lacking, (Qs. Al-Nahl [16]: 71, Al-Isra [17]: 30.

Zakat has a very wide dimension to human beings, not only has the dimension of humanity, but also proves that the human relationship, please 
help among human beings are built on the Divine Foundation. Zakat becomes evidence that Islam is not a religion that forgets the life of the world alone, Zakat is the builder of mankind ${ }^{37}$. Zakat payment is expressed as a sign of righteous believers quality. In conjunction with the Confession of the faith, a believer must establish prayers and perform zakat. This is what demonstrates the significance of one's faith in God. The person who expressed his faith is in Word only, but not paying zakaah can not be considered a true Muslim. There is no action to give evidence of his faith. ${ }^{38}$. Zakat is a religious obligation to be paid by every Muslim who has fulfilled certain requirements.

In the economy zakat has function as alocative and stabilizers. Alocative function, zakat as a tool or instrument to fight poverty. But should be in the distribution pattern, zakat is not only given in the form of consumptive goods but also in the form of production goods. This is done when Mustahiq has the capacity and ability to cultivate and perform production activities. Zakat distribution is encouraged in equity form that is expected to provide a broader impact on economic conditions. ${ }^{39}$ Zakat is a proof of faith in Allah, as well as caring for fellow Muslims in need. Functionally, Zakat has meaning that includes the following things; (a) Zakat aims to improve the welfare of the recipients, among the poor, including assisting in the field of education, health and economic activities, (b) Zakat related to the ethics of work and effort is to seek sustenance that Halal and good, (c) Zakat related to the actualisation of potential and to build the people, such as building excellent educational facilities but cheap, health facilities, economic affairs and other, (d) zakat related to intellectual intelligence, emotional, Spiritual and social, (e) Zakat resulted in peace, happiness, safety and welfare of life (Qs at Taubah [9]: 103), (f) Zakat related to the efforts to develop a property that is cultivated by working and producing it (Qs ar Rum [ 30]: 39), (g) Zakat will cause people to be increasingly doing mahdhah worship, (Qs al Baqarah [2]: 43). (h) Zakat reflects

\footnotetext{
${ }^{37}$ Asnaini, ). Zakat Produktif dalam Persepektif Islam, Pustaka Pelajar, Bengkulu 2008, hlm. 3

38 Al Jazairi, Kitab Fiqh Ala Mazabib Arba'ah, Darul Fikri, Bairut, 2002, hlm.246-247

${ }^{39}$ Hafifuddin, Op.Cit, hlm. 92
} 
sharing spirit that is believed to be the way to overcome economic problems, (i) zakat strongly useful in overcoming various kinds of calamities that occur like natural disasters and other. ${ }^{40}$ In general, zakat function include moral, social and economic areas. In a moral midwife, Zakat is a covetousness and greed of the rich. In the social field, Zakat serves to eliminate poverty from society. In the economic field, zakat prevents the buildup of wealth in the hands of a small part of human beings and is a compulsory contribution of Muslims to the Treasury of the State, because the purpose of zakat is transper wealth from the rich community to the community Underprivileged, so that every activity that is a source of wealth must be a source of zakat. ${ }^{41}$. Zakat turns out to have macroeconomic impacts, namely zakat to influence consumption behaviour, government spending behaviour and investment behaviour $^{42}$. Zakat has a positive influence for economic growthi ${ }^{43}$ economically the aid of zakat given in the form of consumptive on Mustahiq will increase the buying power of the goods that are the need. The increase of purchasing power on an item will affect the increase in production of a company that means the addition of production capacity, this means that the company will absorb more manpower so that it can increase the economy Countries in aggregate ${ }^{44}$

When examined above description of zakat function, it can be understood that zakat role in the economic development of people is very large. Zakat became a very reliable Islamic financial instrument in Islam. History has been noted that when Umar bin Abd Aziz became caliph, it was very difficult to seek MUSTAHIQ/zakat beneficiary at that time. This is due to the empowerment of the equitable and fair zakat. Zakat can used as a working capital for the capital to be reduced according to the skills and skills

40 Ataya, Antara zakat, infaq dan shadaqah, Angkasa, Bandung,, 2013, hlm 11-12

${ }^{41}$ Mannan, Teori dan Praktik Ekonomi Islam, Dana Bhakti Wakaf, Yogyakarta, 1997, hlm 256

${ }^{42}$ Susanto, 2003, Vol IV, No, 2

${ }^{43}$ Karim, Makro ekonomi Islam, Rajagrapindo Persada, Jakartaa, 2007, hlm 133

${ }^{44}$ Kahf, Ekonomi Islam, Pustaka Pelajar, 2000, hlm 57. 
of each of which is at the top of the quality improvement. ${ }^{45}$ Zakat allows to dig a wealth that is buried to be utilized for the welfare of the Greater society ${ }^{46}$. akat can increase the income of weak people and reduce poverty so that the creation of equitable development. ${ }^{47}$

\section{a. Waqf and Waqf role}

Waqf is derived from the Arabic language of the word WAQM which is a form of Masdar of WAQAFA work, it has various meanings following the purpose and use of the verse itself. In terms of language, Waqf gives meaning to stop $^{48}$. ccording to the language, the Arabic word waqaf is copied into the Indonesian language to Waqf, is actually a form of masdar or word from the verb waqafa. Verbs or fiils Waqafa sometimes require an object (Lazaim). The word waqaf is synonymous or synonymous with the word HABS. As such, the word waqaf can mean stopping and stopping ${ }^{49}$. he word waqaf means to withstand, discontinue, or curb. ${ }^{50}$

The terminology of Waqf can be described as follows; According to Imam Abu Hanifah, Waqf is holding a treasure in the hands of the Waqf and the income of an item for righteous charitable purposes, Imam Shafi'i mentioned that Waqf is a required worship. Waqf is valid when the person who Berwaqf (WAKIF) has stated with the words "I have a" endowing "(WAQAAFTU) even without being disconnected by the judge. According to the Maliki sect, Waqf is making the benefits of the object that is both rent and the result to be submitted to the person who is in the form of timed submission in accordance with the desired person whose representative. ${ }^{51}$

conomic development not only with zakat instruments but can also be waqf or with institutional development (institutional building), access, welfare,

\footnotetext{
${ }^{45}$ Sitepu, Pemberdayaan masyarakat Islam melalui pemberdayaan ekonomi umat, jurnal Pengembangan masyarakat Islam, Vol.1, No. 1, 2005

${ }^{46}$ Mannan, Teori dan praktik Ekonomi, Dana Bhakti Wakaf, Yogyakarta, 1993 hlm. 59

47 Mannan, ibid,

48 Mukarram, 1990 hlm, 59

49 Siah Khosyiah, Wakaf dan hibah, Pustaka Setia Bandung, 2010, hlm15

${ }^{50}$ Dirjen Bimbaga Kemenag RI, Ilmu Fikih,Jakarta,1986, hlm207.

${ }^{51}$ Siah Khasyiah, Ibid, hlm 18-19
} 
conscientization dan political participation. ${ }^{52}$ The Waqf system is one of institutional building or also can be called "financial mechanism". The extraordinary potential of Waqf can be a reliable economic redistribution. Conceptualally, Waqf assets can be utilized for service provider projects such as free schools for the poor, and productive waqf projects that can generate income like renting a shopping center building. ${ }^{53}$

Waqf is one of the financial instruments besides zakat. With the great potential of Waqf and the development of Waqf as one social institution can help the activities of the people and overcome the problems of people such as poverty, social gaps and others, Waqf can be one of the instruments Economic development of the people. Waqf is empowered and managed jointly by the community and the government can make a positive contribution in the economic development of the people.

\section{CLOSING}

Based on the above exposure, it can be concluded that; Islamic Economic System (SEI) based on Islamic values that give birth to the economic fundamental values of Keadila, accountability, takaful (Social Security). The principle instilled is Tawhid, Caliph, thus resulted in the purpose of creating prosperity and guarantee the objective of sharia is to protect the faith/religion, soul, reason, descent and property. Its values, principles and objectives distinguish between the Islamic economic system and the other Ecosensory system (capitalist \& socialist). The Islamic Economic System expressly outlines the distribution principle; Prohibit riba and gharar, fair/fairness in distribution, concept of possession and prohibition of stacking treasures to the extent can damage social foundations

To reach the community wellbeing, the Islamic economic system offers several economic development instruments of the people such as; Waqf, and other instruments. If all these instruments can be snare and move together, it is hoped that they can establish a social security that will be able to create the realization of the

52 Mufraini, Akutansi dan manajemen Zakat, Prenada Media Group, Jakarta, 2012, hlm. 92

${ }^{53}$ Nurul Huda, Op.Cit. hlm.143. 
economic development of the people in the framework of welfare in society. Zakat and Waqf who are empowered and managed jointly between the community and the government can make a positive contribution in the economic development of the people.

\section{BIBLIOGRAPHY}

Al Jaziri, Abdurrahman (2002), Book of Fiqh Ala Mazahib Arba'ah, Darul Fikri, Bairut, Lebanon

Abu Ishak as Syathibi,(tt), al muwafaqat fi ushul al syariah, Dar al Ma'rifah

Ataya, Abu Arkam Kamil, 2013, Antara Zakat, Infak, and Shadaqah, Angkasa, Bandung

Asnaini, (2008). Productive Zakat in Islamic perspective, Library teach, Bengkulu

Ali, Muhammad Daud, 1988, Islamic economic system of Zakat and Waqf, UI Press, Jakarta

Ali, Nuruddin Mhd, (2006) Zakat as an instrument in fiscal policy, RajaGrafindo Persada, Jakarta

Chapra, M. Umar, (1993), Islam and Economic Development, Islamabat, IIIT,

Dirjen Bimbaga Kementerian Agama RI,(1986), Ilmu Fikih, Jakarta

FE UI, (2009), Indonesia Economic Outlook 2010, Grasindo, Jakarta,

Hasan, M. Ali, (2015, Zakat and INFAK One solution of social Problema in Indonesia, Prenada Media Group, Jakarta

Hafiduddin, Didin, (2003), Islam Aflikatif, Gema Insani, Jakarta (2001) Zakat in the Modern economy, Gema Insani, Jakarta

Hasan, Muhammad, (2001), Zakat Management, effective zakat management Model, Idea Press Publisher, Yogyakarta

Harahap, Fauzia, Ika Yunia \& Riyadi, Abdul Karim, (2015), Basic principles of Islamic economics, Maqashid al Syari'ah perspective, Prenada Media Group, Jakarta

Huda, Nurul, Cs, 2015, Zakat Micro macro perspective, Prenada Media Group, Jakarta

(2015), Islamic Development Economics, Prenada Media Group, Jakarta

... (2012) Islamic Public finance, Prenada Media Group, Jakarta

(2013), Islamic finance institution, theoretical and practical review, Prenada Media Group, Jakarta.

Inayah, Gazi, (2003), comprehensive theory of Zakat and Taxation, TiaraWacana, Yogyakarta,

Karim, Adiwarman Azwar, (2012), Islamic micro economy, Pt Raja Grapindo Persada, Jakarta

Kahf, Monzer, (1997), Potential Effects of Zakaha on Government Budget, in the IIUM Jornal of Wconomics \& Management, 5 No. 1 year 1997

Mufraini, M. Arief, 2012, Akutansi and Zakat management, Prenada Media Group, Jakarta 
Manan, M. Abdul, (1997), Islamic Economic theory and practice, PT Dana Bhakti Prima Yasa, Yogyakarta

Mardani, (2011) verses and Hadith of sharia economics, Rajawali Press Raja Grapindo Persada, Jakarta

Mustafa, Hasan (2011), Human Behavior in a Psychologisosial perspective, Journal of Business Administration, Vol. 7 No. 2, Fisip Unpar.

Misanam, Munrokhim, DKK, (2007), Text Book Economics of Islam, BI and P3EI, Jakarta,

Mit. Wijaksono, (2009), Pembangunan ekonomi dan ekonomi pembangunan, Telaah istilah dan orientasi dalam konteks studi pembangunan, JESP. Vol.1, 2009

Noor, Ruslan Abdul Ghafur, (2013), concept of distribution in Islamic economics, student library, Yogyakarta

Naqvi, Syaid Nawab Haidar, (1994). Islam, Economics and Society, UK Kegan Paul International,

Okun dan Richadson, (1961), Ekonomic development concepts and meaning, In studies in economic development, New York

Prawiranegara, Syafruddin, (1966), Religious and Moral role in the development of Masyaarakat and Indonesia's economy, star month, Jakarta,

Pusat Bahasa Departemen Pendidikan Nasional (2005), Kamus Besar Bahasa Indonesia, Balai Pustaka, Jakarta

Qardhawi, (1995), Islamic tips to alleviate poverty, Gema Insani Press, Jakarta

Rusli, Achyar, (2005), Zakat = Tax, study of the Hermeneutics of the verses of Zakat in the Qur'an, Renada, Jakarta

Ruslan, Noor Abdul Gafur, (2013), concept of distribution in Islamic economics, student library, Yogyakarta

Rozak, Nasrudin, (1985), Dilul Islam, Al Ma'arif, Bandung

Rahmat Syafei, (2000), Fiqh Muamalah, Pustaka Setia, Bandung

Sadr, Muhammad Baqir, (1994), Iqtisaduna, (Our Economic), Wofis, Tehran,.

Siah Khosyiah (2010), Wakaf dan Hibah, Pustaka Setia Bandung

Sitepu, (2005), Pemberdayaan masyarakat Islam melalui pemberdayaan ekonomi umat, Jurnal Pengembangan masyarakat Islam, Vol.1 tahun 2005

Zuhaili, Wahbah, (2011), Islamic Fiqh wa Adillatuhu, Gema Insani, Darul Fikri, Jakarta 